Hasil Penclitian

\title{
Peran Komite dalam Penyelenggaraan Pendidikan di Madrasah Tsanawiyah Negeri 1 Palembang (studi Manajemen Peningkatan Mutu Berbasis sekolah)
}

\author{
$\mathcal{H}$ Hasnarita
}

\begin{abstract}
The purpose of this study is to know and understand the role of school committees in the provision of education in MTs Negeri 1 Palembang and the impact of school committee role in the provision of education in MTs Negeri 1 Palembang. The results of the research are as follows: The role of the school committee as a deliberation is manifested in the form of input of learning process to the teachers, the consideration of the provision and use of facilities and infrastructure, the consideration of the use and utilization of the budget, the input on the draft budget and expenditure of madrasah (RAPBM ), Held draft budget and madrasah budget (RAPBM) budgets, changed considerations and joined the RAPBM with the headmaster. School committees play a role in the framework of transparency in the use of education funding allocations, including in overseeing the use of grants to be more accountable. The committee also oversees the implementation of the bimbel (additional class hours). The role of the committee as a mediator has so far been the form of a link between the principal and the community, the principal with the education council and the principal with the school itself. The impact of school committee role in education implementation at MTs Negeri 1 Palembang is seen in the implementation of four role of committee which influence either directly or indirectly, but not yet maximal in support of education in MTs Negeri Palembang.
\end{abstract}

Keywords: Role, Committee, Madrasah Tsanawiyah Negeri 1 Palembang

\begin{abstract}
Abstrak
Tujuan penelitian ini adalah mengetahui dan memahami peran komite Sekolah dalam penyelenggaraan pendidikan di MTs Negeri 1 Palembang dan dampak peran Komite Sekolah dalam penyelenggaraan pendidikan di MTs Negeri 1 Palembang. Adapun hasil penelitian diperoleh hasil sebagai berikut: Peran komite sekolah sebagai pemberi pertimbangan diwujudkan dalam bentuk pemberian masukan proses pembelajaran kepada guru-guru, pertimbangan penyediaan dan penggunaan sarana dan prasarana, pertimbangan penggunaan dan pemanfaatan anggaran, masukan tentang rancangan anggaran pendapatan dan belanja madrasah (RAPBM), menyelenggarakan rapat rancangan anggaran pendapatan dan belanja madrasah (RAPBM), pertimbangan perubahan dan ikut mengesahkan RAPBM bersama kepala sekolah. Komite sekolah berperan dalam rangka transparansi penggunaan alokasi dana pendidikan termasuk dalam mengawasi penggunaan dana bantuan agar lebih dapat dipertanggungjawabkan. Komite juga mengawasi pelaksanaan bimbel (jam kelas tambahan). Peran komite sebagai mediator sejauh ini wujudnya berupa penghubung antara kepala sekolah dengan masyarakat, kepala sekolah dengan dewan pendidikan serta kepala sekolah dengan sekolah itu sendiri. Dampak peran Komite Sekolah dalam penyelenggaraan pendidikan di MTs Negeri 1 Palembang terlihat pada terlaksananya empat peran komite yang berpengaruh secara baik secara langsung maupun tidak, akan tetapi belum maksimal dalam menunjang penyelenggaraan pendidikan di MTs Negeri Palembang.
\end{abstract}

Kata kunci: Peran, Komite, Madrasah Tsanawiyah Negeri 1 Palembang 


\section{Haril Penelition}

Pemberlakuan Undang-Undang RI Nomor 22 Tahun 1999 tentang Pemerintahan Daerah membawa angin segar dalam bidang pendidikan. Adanya kebijakan otonomi daerah (desentralisasi) berimplikasi langsung terhadap sistem penyelengaraan pendidikan, di mana kewenangan dan keleluasaan pengelolaan pendidikan diserahkan kepada pemerintah kota/kabupaten. Selanjutnya Penerapan Manajemen Berbasis Sekolah (MBS) di jamin oleh undang-undang Nomor 20 Tahun 2003 tentang Sistem Pendidikan Nasional, pasal 51. Pasal 51 UU No.20/2003 menyatakan sebagai berikut: 1) Pengelolaan satuan pendidikan anak usia dini, pendidikan dasar dan pendidikan menengah dilaksanakan berdasarkan standar pelayanan minimal dengan prinsip Majemen Berbasis Sekolah; 2) Pengelolaan satuan pendidikan dilaksanakan berdasarkan prinsip otonomi, akuntabilitas, janiman mutu dan evaluasi yang transparan; dan 3) Ketentuan mengenai pengelolaan satuan pendidikan sebagaimana dimaksud pada ayat (1) dan ayat (2) diatur lebih lanjut dengan peraturan pemerintah.

Undang-undang Sisdiknas Nomor 20 Tahun 2003 memberikan landasan hukum yang kuat untuk diterapkannya Manajemen Berbasis Sekolah atau Community Based Education. Gagasan-gagasan berdasarkan hasil studi baik di luar maupun di dalam negeri, tentang effective school (sekolah yang efektif) yang hanya mungkin direalisasikan jika Manajemen Berbasis Sekolah diterapkan, serasa memperoleh peluang dalam suasana reformasi di bidang pendidikan dengan tema otonomi pedagogis sehingga turut mendorong diperkenalkannya Manajemen Berbasis Sekolah di Indonesia.

Seiring otonomisasi tersebut, dilakukan pula pengembangan suatu pendekatan "baru", yakni manajemen berbasis sekolah/MBS (school based management). Pelaksanaan Manajemen Berbasis Sekolah, yang kemudian ditegaskan melalui Program Manajemen Peningkatan Mutu Berbasis Sekolah (MPMBS), dinilai banyak pengamat pendidikan sebagai program strategis untuk meningkatkan kinerja sekolah dalam menghasilkan jasa pendidikan berkualitas prima, terutama dalam aspek pelayanan masyarakat dan optimalisasi kemampuan belajar (learning capacity) peserta didik.
Untuk menjalankan perannya komite sekolah mempunyai fungsi sebagai berikut: 1) Mendorong tumbuhnya perhatian dan komitmen masyarakat terhadap penyelenggaraan pendidikan yang bermutu; 2) Melakukan upaya kerja sama dengan masyarakat (perorangan/organisasi/dunia usaha/dunia industri) dan pemerintah berkenaan dengan penyelenggaraan pendidikan yang bermutu; 3) Menampung dan menganalisis aspirasi, ide, tuntutan, dan berbagai kebutuhan. pendidikan yang di ajukan oeh masyarakat; 4) Memberikan masukan, pertimbangan, dan rekomendasi kepada satuan pendidikan mengenai Kebijakan dan program pendidikan, Rencana Anggaran Pendidikan dan Belanja Sekolah (RAPBS), Kriteria kinerja satuan pendidikan, Kriteria tenaga pendidikan, Kriteria fasilitas pendidikan, Hal-hal lain yang berkaitan dengan pendidikan; 5) Mendorong orang tua dan masyarakat berpatisipasi dalam pendidikan guna mendukung peningkatan mutu dan pemerataan pendidikan; 6) Menggalang dana masyarakat dalam rangka pembiayaaan penyelenggaraan pendidikan di satuan pendidikan; 7) Melakukan evaluasi dan pengawasan terhadap kebijkan, program, penyelenggaraan dan keluaran pendidikan di satuan pendidikan.

Bersandar dari teori di atas berikut ditemukan fakta-fakta berkenaan dengan komite sekolah di MTs Negeri 1 Palembang: 1) Komite Sekolah sudah terbentuk sejak tahun pelajaran 2002/2003. Setelah terbentuknya komite sekolah pada setiap satuan pendidikan, pengurus dan anggota Komite Sekolah harus menyusun Anggaran Dasar (AD)/Anggaran Rumah Tangga (ART) untuk mengatur tata laksana pengelolaan Komite Sekolah, termasuk di dalamnya mekanisme pembentukan Komite Sekolah priode berikutnya. Dari hasil penelitian awal yang dilakukan pada MTs Negeri 1 Palembang anggaran dasar dan anggaran rumah tangga komite sudah ada; 2) Pemberdayaan yang dilakukan terhadap Komite Sekolah adalah sosialisasi tentang peran Komite Sekolah dalam penyelenggaraan pendidikan di MTs Negeri 1 Palembang; 3) Komite Sekolah pada prinsipnya masih sebatas melaksanakan rapat maupun pertemuan kepala sekolah, komite sekolah, tokoh masyarakat dan guru tentang perencanaan dalam rangka pembuatan Rencana Program Sekolah (RPS) dan Rencana Anggaran Pendapatan Belanja 


\section{Hasil Penelitian}

Sekolah (RAPBS); dan 4) Adanya pendapat dari beberapa orang tua siswa/masyarakat yang beranggapan bahwa fungsi Komite Sekolah tidak jauh beda dengan apa yang dilakukan oleh BP3 yang tidak berhasil memobilisasi partisiapasi dan tanggung jawab masyarakat (Darmansyah, Wawancara: 16-9-2016).

Dari berbagai studi dan pengamatan langsung di lapangan, hasil analisis menunjukkan bahwa paling tidak ada tiga faktor yang menyebabkan mutu pendidikan tidak mengalami peningkatan secara merata. Pertama, kebijakan penyelenggaraan pendidikan nasional yang berorientasi pada keluaran pendidikan (output) terlalu memusatkan pada masukan (input) dan kurang memperhatikan pada proses pendidikan. Kedua, penyelengaraan pendidikan dilakukan secara sentralistik. Hal ini menyebabkan tingginya ketergantungan kepada keputusan birokrasi dan seringkali kebijakan pusat terlalu umum dan kurang menyentuh atau kurang sesuai dengan situasi dan kondisi sekolah setempat.

Dengan demikian, sekolah harus menjalin komunikasi yang transparan dengan masyarakat dan orang tua siswa. Setiap aktivitas pendidikan (terutama) yang bersifat inovatif sudah sepatutnya dikomunikasikan terlebih dahulu kepada masyarakat. Hal itu dimaksudkan agar mereka, sebagai salah satu penanggungjawab lembaga, dapat lebih mengerti serta memahami akan peran dan fungsinya terhadap aktivitas yang diadakan (Pidarta, tt: 194).

Manajemen Berbasis Sekolah dapat didefinisikan sebagai segala sesuatu yang berkenaan dengan pengelolaan sumber daya yang berdasar pada sekolah itu sendiri dalam proses pembelajaran untuk mencapai tujuan yang telah ditetapkan (Mauludin, 2003: 1). Berdasarkan kondisi yang dijelaskan dalam latar belakang di atas, maka peneliti perlu melakukan penelitian ini dengan judul "Peran Komite Dalam Penyelenggaraan Pendidikan di Madrasah Tsanawiyah Negeri 1 Palembang (Studi Manajemen Peningkatan Mutu Berbasis Sekolah)"

Peran Komite Sekolah dalam Penyelenggaraan pendidikan di MTs Negeri 1 Palembang Peran Komite Sebagai Pendukung (Supporting Agency)
Berkenaan dengan hal ini berikut jawaban narasumber mengenai pertanyaan "dalam penyelenggaran pendidikan peran komite sebagai pendukung adalah hal penting, bagaimana dengan komite MTs N 1 Palembang selama ini?

Berikut jawaban bapak YHD selaku kepala madrasah MTs N 1 Palembang: "Dukungan yang diberikan oleh komite sekolah dalam meningkatkan mutu pendidikan dalam bentuk materiil, materiil di sini dalam bentuk barang misalnya saja penambahan komputer, pemberian buku-buku pelajaran untuk melengkapi perpustakaan, komite juga memberikan dukungan moril kepada semua pihak sekolah supaya lebih mengembangkan mutu pendidikan (Darmansyah, Wawancara: 3-8-2016)."

Sedangkan pendapat bapak US selaku ketua komite yaitu "Menurut penadapat saya dan sejauh pengamatan saya komite sekolah sangat mendukung sekolah dalam melaksanakan program sekolah dan usaha sekolah dalam meningkatkan mutu, dukungan yang diberikan komite sekolah dalam bentuk materiil dan berupa beberapa saran atau masukan demi tercapainya tujuan sekolah dan ercapainya mutu yang lebih baik lagi "(Saleh, Wawancara: 6-2-2017).

Kemudian utnuk pertanyaa "Langkah apa saja yang dilakukan komite guna memenuhi peran pendukung penyelenggaraan pendidikan di MTs N 1 Palembang yang berwujud moril atau materil saja?

Berdasarkan observasi dan wawancara dapat diketahui dukungan yang diberikan oleh komite sekolah dalam meningkatkan mutu pendidikan hanya berupa dukungan materiil dan moril.

Menurut ibu RK:"Dukungan yang diberikan oleh komite sekolah dalam meningkatkan mutu pendidikan dalam bentuk materiil, materiil di sini dalam bentuk barang misalnya saja penambahan komputer, pemberian buku-buku pelajaran untuk melengkapi perpustakaan, komite juga memberikan dukungan moril kepada semua pihak sekolah supaya lebih mengembangkan mutu pendidikan (Rismalakusuma, Wawancara: 6-82016)."

Bapak ZA juga mengatakan: "Dukungan yang diberikan oleh komite sekolah terhadap sekolah ini berupa dukungan materiil dan non materiil, non disini dalam bentuk saran atau 


\section{Haril Penelitian}

masukan yang menunjang peningkatan mutu sekolah (Arifin, Wawancara: 3-8-2-16).”

Bapak YHD mengatakan: "Dukungan yang diberikan komite tentunya dalam bentuk materiil misalnya saja dalam bentuk pemberian buku untuk melengkapi perpustakaan dan pemberian sarana lain yang dibutuhkan oleh murid ya walaupun tidak dalam jumlah besar (Darmansyah, Wawancara: 3-8-2016).

Bentuk dukungan lain berupa pemantauan terhadap kondisi dari pada tenaga pendidik atau guru dan non pendidik dalam hal ini adalahstaf karyawan merupakan dukungan moriil yang diberikan komitesekolah, selain itu dukungan yang diberikan juga berupa pemantauankondisi sarana dan prasarana yang ada di sekolah. Melakukankoordinasi dukungan sarana dan prasrana di sekolah, memantau kondisianggaran pendidikan sekolah, dan mengevaluasi pelaksanaan dukungananggaran sekolah.

Bapak MR selaku wakil ketua komite MTs N 1 Palembang menjelaskan: "Dukungan yang diberikan oleh komite sekolah terhadap sekolah ini berupa dukungan materiil dan non materiil, non disini dalam bentuk saran atau masukan yang menunjang peningkatan mutu sekolah (Refli, Wawancara: 1-8-2016).”

Bapak OR selaku sekertaris komite MTs N 1 Palembang menjelaskan:"Dukungan yang diberikan komite tentunya dalam bentuk materiil misalnya saja dalam bentuk pemberian buku untuk melengkapi perpustakaan dan pemberian sarana lain yang dibutuhkan oleh murid ya walaupun tidak dalam jumlah besar (Oktorisman, Wawancara: 1-82016)."

Untuk mencapai semua itu, penyelenggaraan pendidikan bukan hanya menjadi tanggung jawab pemeritah semata, namun menjadi tanggung jawab semua pihak, termasuk tanggungjawab dan peran serta masyarakat melalui stakeholder pendidikan yang bersentuhan langsung dengan penyelenggaraan pendidikan di lapisan yang paling bawah.

Secara mudahnya pelibatan komite sekolah dalam penyelenggaraan pendidikan di sekolah adalah bentuk usaha memberrdayakan semua aspek yang ada dalam komite sekolah guna menunjang proses pendidikan disekolah ke arah yang lebih baik. Artinya sudah seharusnya komite proaktif dalam setiap hal yang berkenaan dengan proses pendidikan disekolah termasuk juga komite dilingkungan MTs Negeri 1 Palembang. Berikut dijelaskan oleh narasumber di bawah ini mengenai pertanyaan "Bagaimana dengan dukungan tenaga dan waktu dalam penyelenggaraan pendidikan, apakah komite MTs N 1 Palembang juga berperan

Berikut bapak US ketua komite menjelaskan berkenaan dengan dukungan komite di MTs Negeri 1 Palembang:"Melibatkan komite sekolah artinya memberikan peluang kepada komite menjalankan fungsi-fungsi komite sebagaimana mestinya, misalnya fungsi sebagai badan pertimbangan dalam penyelenggaraan pendidikan, untuk komite MTs Negeri 1 Palembang, alhamdulillah selalu dilibatkan terutama perangkat komite yang ada. Meski ada cela kekurangan pada anggota komite biasanya berhalangan hadir karena ada kesibukan lain seperti bekerja (Saleh, wawancara: 6-2-2017)".

Apa yang dijelaskan oleh ketua komite di atas juga diperjelas oleh keterangan kepala madrasah bapak YHD sebagai berikut: "Selama ini pihak madrasah sudah berusaha melibatkan komite dalam menetapkan hal-hal yang berkenaan dengan proses pendidikan di MTs Negeri 1 Palembang ini, sebagai contoh dalam memberikan pertimbangan terhadap penyusunan Rencana Kerja dan Anggaran Madrasah, menyosialisasikan Rencana Kerja dan Anggaran Madrasah, bersama sekolah mengesahkan Rencana Kerja dan Anggaran Madrasah yang dilakukan pada setiap awal semester, baik dalam bentuk evaluasi maupun rencana baru. Hal ini tentu artinya sekolah telah berusaha melibatkan komite dalam hal bentuk tenaga dan waktu ((Darmansyah, Wawancara: 3-82016).

Dari apa yang dijelaskan ketua komite dan kepala madrasah MTs Negeri Palembang dapat diketahui bahwa pihak MTs Negeri 1 Palembang sudah melibatkan komite sekolah dalam perencanaan pendidikan di MTs Negeri 1 Palembang, namun masih ada dari anggota komite yang berhalangan hadir. Hal ini menunjukkan bahwa komite sekolah sudah terlibat dalam pengambilan keputusan penting seperti dalam rapat Rencana Kerja dan Anggaran Madrasah. 


\section{Hasil Penelitian}

\section{Peran Komite Sebagai Pemberi pertimbangan (Advisory Agency)}

Pada kenyataannya tidak semua peran itu dilakukan komite sekolah yang ada disekolah, salah satunya seperti komite sekolah yang ada di MTs Negeri 1 Palembang. Komite sekolah hanya berperan dalam pemberi pertimbangan dalam hal sarana dan prasarana saja itu pun juga harus dirembug lagi dengan yayasan jika yayasan setuju atas usulan tersebut baru akan dikerjakan. Komite sekolah tidak ikut campur dalam pemberian pertimbangan atas penggunaan dana yang berasal dari orang tua murid. Tapi komite sekolah ikut memberikan pertimbangan atasdana penggunaan dana yang berasal dari pemerintah daerah.

Berikut kutipan wawancara yang peneliti lakukan dengan pihak sekolah: Bapak US mengatakan: "keberadaan komite sekolah disini kurang begitu berpengaruh, disekolah ini malah lebih berpengaruh KEMENAG, komite sekolah itu bisa dikatakan pelengkap saja, namun tetap mempunyai peran dan fungsi walaupun, misalnya peranya sebagai pemberi pertimbangan, komite sekolah hanya memberikan pertimbangan dalam hal sarana dan prasarana saja dalam hal pertimbangan lain komite sekolah tidak berperan, pembuatan laborat komputer dan mushola disini atas saran dari pada komite yang kemudian ditindak lanjuti oleh pihak madrasah (Saleh, Wawancara: 6-2-2017)."

Bapak OR juga mengatakan: "yang saya ketahui komite sekolah disini keberadaannya hanya sebagai pelengkap saja karena kedudukan komite sekolah tidak begitu berpengaruh malah justru lebih berpengaruh KEMENAG tapi di sini tetap ada komite sekolah, sepengetahuan saya peran komite sekolah sebagai pemberi pertimbangan hanya dalam hal fisik saja, misalnya pertimbangan penambahan ruangan kelas atau sarana lain yang dibutuhkan oleh sekolah ini, dalam hal penggnaan dana yang berasal dari orang tua murid komite sekolah tidak ikut campur tapi kalau dana dari pemerintah daerah komite sekolah memberikan pertimbangan dalam penggunaannya (Oktorisman, wawancara: 1-8-2017).

Tugas dan fungsi Komite Sekolah antara lain : (1) menetapkan $\mathrm{AD}$ dan ART Komite Sekolah, memberi masukan terhadap muatan RAPBS dan Rencana Strategis Pengembangan serta
Pelayanan Sekolah; (2) menentukan dan membantu kesejahteraan personal, mengkaji pertanggungjawaban dan impelementasinya; (3) mengkaji kinerja sekolah dan melakukan internal auditing (school self assessment), merekomendasikan, menerima kepala sekolah dan guru. Komite Sekolah membantu harus turut menjaga penjaminan mutu sekolah (quality assurance), memelihara, mengembangkan potensi, menggali sumber dana, mengevaluasi, merenovasi, mengidentifikasi, dan mengelola kontribusi masyarakat terhadap sekolah sebagai satuan pendidikan. Gambaran di atas menyiratkan bahwa, secara luas Komite Sekolah berfungsi sebagai mitra sekolah yang memiliki peran penting guna menunjang kemajuan sekolah.

Kemudian hal-hal yang berkaitan cara yang dilakukan dalam mengembangkan rencana untuk mengkoordinasi aktivitas komite MTs N 1 Palembang? Berikut kutipan wawancara yang peneliti lakukan dengan narasumber:

Ibu RN berpendapat: "keberadaan komite sekolah disini kurang begitu berpengaruh, disekolah ini malah lebih berpengaruh KEMENAG, komite sekolah itu bisa dikatakan pelengkap saja, namun tetap mempunyai peran dan fungsi walaupun, misalnya peranya sebagai pemberi pertimbangan, komite sekolah hanya memberikan pertimbangan dalam hal sarana dan prasarana saja dalam hal pertimbangan lain komite sekolah tidak berperan, pembuatan laborat komputer dan mushola disini atas saran dari pada komite yang kemudian ditindak lanjuti oleh pihak sekolah (Nafiz, wawancara: 2-8-2016)."

\section{Peran Komite Sebagai Pengontrol (controling Agency)}

Dalam rangka transparansi penyelenggaraan dan keluaran pendidikan di MTs N 1 Palembang sejauh mana komite dilibatkan selama ini?

Selain dalam hal perencanaan masih banyak lagi manfaat keterlibatan komite dalam penyelnggaraan pendidikan di MTs Negeri 1 Palembang 'seperti dijelaskan oleh MR, Wakil Ketua Komite MTs Negeri 1 Palembang: "Tak dapat dipungkiri bahwa pendidikan di samping mempunyai manfaat ekonomi juga mempunyai manfaat sosial-psikologis yang sulit dianalisis 
secara ekonomi. Namun, pendekatan ekonomi dalam menganalisis pendidikan memberikan kontribusi sekurang-kurangnya terhadap 2 hal, yaitu: (1) Analisis efektifitas dalam arti analisis penggunaan biaya-biaya yang dimanfaatkan untuk mencapai tujuan-tujuan pendidikan; (2) Analisis efisiensi penyelenggaraan pendidikan dalam arti perbandingan hasil dengan sejumlah pengorbanan yang diberikan khususnya di MTs Negeri 1 Palemabang ini (Refli, wawancara: 1-8-2016)"

Implementasi pembiayaan sumber dana pendidikan di tingkat daerah, maka sumber pendanaan pendidikanpun dikelola dan diselenggarakan oleh pemerintah kabupaten/kota yang dimuat dalam APBD. Maksudnya adalah bahwa semua kewenangan dan pengelolaan sumber pendanaan pendidikan di Indonesia. Guna mengumpulkan data mengenai pembiayaan yang di awasi komite diajukan Demokratis penyelenggaraan dan keluaran pendidikan di satuan pendidikan adalah hal penting dan merupakan salah satu peran komite, bagaimana dengan komite MTs N 1 Palembang?

Dalam hal ini ibu RK berpendapat: "Hal klasik yang selalu menjadi salah satu faktor penghambat kemajuan pendidikan di tingkat satuan pendidikan adalah faktor biaya, yaitu minim dan terbatasnya pendanaan biaya penunjang pendidikan sebagai alat untuk penunjang peningkatan mutu pendidikan. Biaya sangat mempengaruhi penyelenggaraan pendidikan yang dianggap memiliki nilai strategis dalam upaya penopang kinerja peningkatan dan penunjang peningkatan mutu pendidikan secara kontinyu (Rismalakusuma, wawancara: 1-8-2016).

Apa yang disampaikan oleh ibu RK di atas di perjelas lagi oleh narasumber ZA di bawah ini: "Di era Otonomi Daerah dan Otonomi Sekolah, seharusnya komite sekolah tidak lagi sebagai organisasi yang mencari dana yang kemudian dikelola oleh sekolah secara organisatoris, tetapi diharapkan mampu untuk mengelola dan mempertanggungjawabkan sendiri sumber dana yang didapatnya. Selain itu juga, komite harus berperan aktif dalam pelaksanaan pengawasan penyelenggaraan pendidikan yang dilaksanakan oleh sekolah sebagai satuan pendidikan penyelenggara pendidikan secara keseluruhan. Komite sekolah tidak lagi berperan sebagai stempel dan mesin uang sekolah, tetapi harus berperan sebagai sebuah organisasi yang memiliki kewenangan dalam pengawasan pendidikan secara ekternal (Arifin, wawancara: 3-8-2016).

Akuntanbilitas penyelenggaraan dan keluaran pendidikan adalah termasuk tolok ukur keberhasilan dalam pendidikan, selama ini apakan komite sudah optimal dalam memberikan kontrol hal ini?

Peran komite sebagai pengontrol perwujudannya adalah dalam bentuk pengawasan terhadap proses pengambilan keputusan disekolah, melakukan penilaian terhadap kualitas kebijakan yang diambil sekolah, melakukan pengawasan terhadap proses dan kualitas perencanaan dan program sekolah, melakukan pengawasan terhadap organisasi sekolah, melakukan pengawasan terhadap alokasi anggaran untuk pelaksanaan program sekolah dan melakukan pengawasan terhadap partisipasi sekolah pada program sekolah.

Bapak YHD menjelaskan: "kontrol yang dilakukan oleh komite sekolah selama ini dalam proses pengambilan keputusan disekolah, selain itu juga melakukan pengawasan terhadap proses dan kualitas perencanaan dan program sekolah dan melakukan pengawasan terhadap organisasi sekolah (Darmansyah, wawancara: 3-8-2016)."

Sedang bapak HS mengatakan: "iya komite sekolah kadang melakukan kontrol mulai dari sudah terlaksananya atau belum program sekolah (Hasan, wawancara: 1-8-2016).”

Bapak YHD menjelaskan: "Komite sekolah juga mengawasi penggunaan alokasi dana pendidikan termasuk penggunaan dana bantuan dari pusat yang mengalir ke sekolah (Darmansyah, wawancara: 3-8-2016)."

Sedangkan bapak HS berpendapat: "kontrol juga dilakukan dalam hal perolehan dan penggunaan anggaran atau dana sekolah tapi hanya dana yang berasal dari pemerintah daerah saja kalau dana yang berasal dari orang tua komite sekolah tidak ikut campur didalamnya (Hasan, wawancara: 1-8-2016)."

Peran komite sebagai pengontrol perwujudannya adalah dalam bentuk pengawasan terhadap proses pengambilan keputusan disekolah, melakukan penilaian terhadap kualitas kebijakan yang diambil sekolah, melakukan pengawasan terhadap proses dan kualitas perencanaan dan 


\section{Haril Penelitian}

program sekolah, melakukan pengawasan terhadap organisasi sekolah, melakukan pengawasan terhadap alokasi anggaran untuk pelaksanaan program sekolah dan melakukan pengawasan terhadap partisipasi sekolah pada program sekolah.

Bapak OR berpendapat:“Kontrol yang dilakukan oleh komite sekolah selama ini dalam proses pengambilan keputusan disekolah, selain itu juga melakukan pengawasan terhadap proses dan kualitas perencanaan dan program sekolah dan melakukan pengawasan terhadap organisasi sekolah (Oktorisman, wawancara: 1-8-2016)."

Selain itu komite sekolah juga berperan serta dalam rangka transparansi penggunaan alokasi dana pendidikan termasuk dalam mengawasi penggunaan dana bantuan dari pusat yang mengalir kesekolah agar lebih dapat dipertanggungjawabkan. Penggunaan dana baik yang berasal dari masyarakat maupun pemerintah dapat benar-benar efektif dan termonitor alokasinya, apakah sesuai dengan kebutuhan atau tidak.

Rancangan Anggaran Pendapatan dan Belanja Madrasah (RAPBM) yang diajukan satuan pendidikan/sekolah. Di MTs Negeri 1 Palembang sendiri penggunaan atau pengelolaan dana sekolah yang berasal dari pusat atau pemerintah daerah memang diawasi oleh komite sekolah setiap pemasukan dan pengerluaran yang ada selalu dilaporkan kepada komite sekolah. Seperti halnya dikatakan oleh narasumber dalam wawancara dengan peneliti.

Bapak HS mengatakan: "Komite sekolah juga mengawasipenggunaan alokasi dana pendidikan termasuk penggunaan dana bantuan dari pusat yang mengalir ke sekolah (Hasan, wawancara: 1-8-2016)."

Sedangkan bapk OR berpendapat: "Kontrol juga dilakukan dalam hal perolehan dan penggunaan anggaran atau dana sekolah tapi hanya dana yang berasal dari pemerintah daerah saja kalau dana yang berasal dari orang tua komite tidak ikut campur didalamnya (Oktorisman, wawancara: 1-8-2016)."

Selain melakukan kontrol pada hal-hal di atas Komite Sekolah MTs Negeri 1 Palembang juga melakukan kontrol pada proses pengelolaan keuangan sekolah, berikut keterangan narasumber penelitian berkenaan dengan pengelolaan keuangan sekolah:
Pengawasan keuangan di MTs Negeri 1 Palembang di jelaskan oleh guru BJ selaku sekretaris madrasah mengatakan:"Bahwasanya pengawasan dilakukan oleh kepala madrasah dan instansi vertikal di atasnya termasuk juga pihak komite, serta aparat pemeriksa keuangan pemerintah.terkait dengan pengawasan luar madrasah, Kepala Madrasah bertugas menggerakkan semua unsur yang terkait dengan pengawasan agar menyediakan data yang dibutuhkan oleh pengawas. Dalam hal ini Kepala Madrasah bertugas mengkoordinasikan semua unsur terkait dengan materi pengawasan sehingga kegiatan pengawasan berjalan lancar (Jusanti, wawancara: 6-2-2017).

Pada dasarnya kegiatan pengawasan pelaksanaan anggaran dilakukan dengan maksud untuk mengetahui kesesuaian pelaksanaan anggaran dengan ketentuan yang telah ditetapkan dan dengan prosedur yang berlaku, kesesuaian hasil yang dicapai baik di bidang tekhnis administratif maupun tekhnis operasionalnya dengan peraturan yang ditetapkan. Selanjutnya kemanfaatan sarana yang ada (manusia, biaya, perlengkapan dan organisasi) secara efisien dan efektif, serta sistem yang lain atau perubahan sistemguna mencapai hasil yang lebih sempurna. Pengawasan pun bisa dilakukan melalui pemeriksaan kas, pemeriksaan adalah suatu proses sistematis untuk memperoleh bukti secara objektif tentang pernyataan berbagai kejadian/kegiatan sekolah dengan tujuan untuk menetapkan tingkat kesesuaian antara pernyataan pernyataan tersebut dengan kriteria yang telah ditetapkan, dan penyampaian hasil-hasilnya kepada yang berkepentingan.

Narasumber US mengatakan Pelaporan dan pertanggungjawaban atau lebih dikenal dengan sebutan LPJ Penerimaan dan pengeluaran keuangan sekolah harus dilaporkan dan dipertanggungjawabkan secara rutin sesuai peraturan yang berlaku. Pelaporan dan pertanggungjawaban anggaran yang berasal dari orang tua siswa dan masyarakat dilakukan secara rinci dan transparan sesuai dengan sumber dananya. Pelaporan dan pertanggungjawaban anggaran berasal dari usaha mandiri sekolah dilakukan secara rinci dan transparan kepada dewan guru staf madrasah juga kepada pihak Komite Sekolah (Saleh, wawancara: 6-2-2017)." 


\section{Haril Penelitian}

Auditing atau pemeriksaan adalah semua kegiatan yang menyangkut pertanggungjawaban penerimaan, penyimpanan, dan pembayaran atau penyerahan uang yang dilakukan oleh bendaharawan kepada pihak-pihak yang berwenang. Pemeriksaan bermanfaat sekurangkurangnya bagi empat pihak yaitu bendaharawan, lembaga, atasan, dan badan pemeriksa keuangan. Bagi bendaharawan, pemeriksaan atau auditing berguna untuk: memberikan arah kerja yang pasti,memberikan target kerja yang sudah tertentu, sebagai sarana pengukuran dan penghargaan atas tingkat keterampilan, mengetahui dengan jelas batas wewenang dan kewajibanya, mengontrol diri agar terhindar dari godaan penyalahgunaan uang.

"Menurut ibu BS pengontrolan pendanaan dan kegunaannya dilakukan melalui bentuk laporan pertanggungjawaban yang dibuat dalam setiap kegiatan dilaksanakan dan di bukukan dalam bentuk laporan yang kemudian akan dilaporkan ke pimpinan, kegiatan ini dilakukan untuk membuat segala sesuatu bentuk pendanaan dari pengeluaran sampai dengan penggunaan terarah secara efektif dan efisien" (Jusanti, wawancara: 6-2-2017).

Sedangkan manajemen keuangan bertujuan untuk menjamin agar dana yangtersedia digunakan untuk kegiatan harian sekolah dan kelebihan dana yang ada diinvestasikan kembali. Selanjutnya tujuan dari manajemen keuangan adalah memelihara aset sekolah, daan menjaga agar peratiran-peraturan serta praktik penerimaan, pencatatan, dan pengeluaran uang diketahui dan dilaksanakan.

"Sesuai dengan penjelasan bapak US bahwa pendanaan Madrasah ini juga didapatkan melalui bantuan pemerintah untuk pembangunan madrasah. Selain itu, dana yang di dapat juga dikontrol pihak terkait seperti komite sekolah. Hal ini juga kami pikir sangat berguna untuk kemajuan dan perkembangan madrasah yang dikelola".

Dari penjelasan diatas dapat disimpulkan bahwa pendanaan yang didapat tidak hanya melalui SPP santri saja tetapi dana madrasah ini juga didapat melalui bantuan pemerintah dan donatur atau masyarakat yang ada disekitar Madrasah.

\section{Peran Komite Sebagai Mediator}

Bagaimana komite menjalankan peran sebagai mediator baik antara pemerintah (executive) dengan masyarakat maupun sekolah dan pihak stakeholder lainnya misalnya wali murid di MTs $\quad \mathrm{N} \quad 1$ Palembang?

Ibu RN mengatakan: "Komite sekolah sebagai salah satu unsur yang memiliki kewenangan dan tanggung jawab suksesnya pendidikan di satuan pendidikan, memiliki peran sentral sebagai mitra sekolah dalam memajukan mutu layanan pendidikan di satuan pendidikan. Diharapkan wujud kinerja kolektif dapat tercapainya searah kepada visi dan misi, serta tujuan pendidikan nasional secara utuh khususnya di MTs Negeri 1 Palembang ini, menyeluruh dan berkelanjutan melalui upaya pemberdayaan dan pengembangan tanggung jawab sebagai bentuk peran dan partispasi aktif masyarakat dalam penyelanggaraan pendidikan sebagai upaya meningkatkan mutu pendidikan di masyarakat (Nafiz, wawancara: 2-8-2016).

Peran komite sebagai mediator sejauh ini wujudnya berupa penghubung antara kepala sekolah dengan masyarakat, kepala sekolah dengan dewan pendidikan serta kepala sekolah dengan sekolah itu sendiri dalam hal ini guru, staf karyawan serta murid, selain itu komite juga ikut serta dalam membuat usulan kebijakan dan beberapa program pendidikan kepada sekolah. Seperti hasil wawancara yang dilakukan peneliti dengan narasumber di bawah ini.

Bapak MR mengatakan:"sejauh ini komite sekolah berperan menjadi penampung aspirasi masyarakat dalam hal ini berupa pengaduan dan keluhan terhadap kebijakan dan program pendidikan dan menyampaikannya keluhan tersebut kepada instansi terkait dalam bidang pendidikan di sekolah. Komite sekolah juga menjadi penghubung antara sekolah dengan dewan pendidikan, komite sekolah sebagai mediator juga sering mengadakan diskusi antara pihak sekolah dengan perwakilan wali murid (Refli, wawancara: 1-8-2016).

Komite sekolah juga menjadi penampung aspirasi masyarakat dalam hal ini berupa pengaduan dan keluhan terhadap kebijakan dan program pendidikan dan menyampaikannya keluhan tersebut kepada instansi terkait dalam bidang pendidikan di sekolah.

Bapak ZA berpendapat: "Intinya bahwa peran serta dan partisipasi masyarakat dalam pendidikan akan tercermin dalam model pengelolaan pendidikan sesuai dengan tujuan 


\section{Hasil Penelitian}

Manajemen Berbasis Sekolah (MBS), yaitu meningkatkan kinerja sekolah secara optimal melalui penerapan prinsip-prinsip tata kelola yang baik, meliputi kualitas, inovasi, efektivitas, efisiensi dan produktivitas (Arifin, wawancara: 3-8-2016)."

Selama ini peran serta masyarakat dalam membantu peningkatan mutu pembelajaran di sekolah masih sangat kurang. Banyak faktor selain letak geografis, latar belakang pendidikan juta tingkat pendapatan masyarakat yang kebanyakan petani masih kurang.

Menurut keputusan Mendiknas No. 044/U/2002, tugas dan peran Komite Sekolah ada empat macam, yaitu: 1) Memberikan pertimbangan dalam penentuan dan pelaksanaan kebijakan pendidikan; 2) Memberikan sumbangan pemikira, dana dan tenaga dalam menyelenggarakan pendidikan; 3) Melakukan kontrol terhadap transparansi dan akuntabilitas penyelenggaraan dan keluaran pendidikan; dan 4) Penghubung antara sekolah dengan masyarakat dan pemerintah.

Agar sekolah dapat melaksanakan tugasnya dengan mutu yang baik, pran serta Komite Sekolah untuk terlibat secara aktif dalam penyelenggaraan pendidikan, sangat menentukan.

Untuk mengetahui sejauh mana peran serta masyarakat berpartisipasi aktif dalam pengambilan berbagai kebijakan sekolah akan mendorong kualitas pengelolaan pendidikan di sekolah,gar sekolah dapat melaksanakan tugasnya dengan mutu yang baik, pran serta Komite Sekolah untuk terlibat secara aktif dalam penyelenggaraan pendidikan, sangat menentukan.

Bapak YHD mengatakan: untuk mengetahui sejauh mana peran serta masyarakat berpartisipasi aktif dalam pengambilan berbagai kebijakan sekolah akan mendorong kualitas pengelolaan pendidikan di sekolah,gar sekolah dapat melaksanakan tugasnya dengan mutu yang baik, peran serta Komite Sekolah untuk terlibat secara aktif dalam penyelenggaraan pendidikan, sangat menentukan (Darmansyah, wawancara: 38-2016)

Peran komite sebagai mediator sejauh ini wujudnya berupa penghubung antara kepala sekolah dengan masyarakat, kepala sekolah dengan dewan pendidikan serta kepala sekolah dengan sekolah itu sendiri dalam hal ini guru, staf karyawan serta murid, selain itu komite juga ikut serta dalam membuat usulan kebijakan dan beberapa program pendidikan kepada sekolah. Seperti hasil wawancara yang dilakukan peneliti dengan narasumber berikut:

Bapak MR berpendapat:"sejauh ini komite sekolah berperan menjadi penampung aspirasi masyarakat dalam hal ini berupa pengaduan dan keluhan terhadap kebijakan dan program pendidikan dan menyampaikannya keluhan tersebut kepada instansi terkait dalam bidang pendidikan di sekolah. Komite sekolah juga menjadi penghubung antara sekolah dengan dewan pendidikan, komite sekolah sebagai mediator juga sering mengadakan diskusi antara pihak sekolah dengan perwakilan wali murid (Refli, wawancara: 1-8-2016)."

Komite sekolah juga menjadi penampung aspirasi masyarakat dalam hal ini berupa pengaduan dan keluhan terhadap kebijakan dan program pendidikan dan menyampaikannya keluhan tersebut kepada instansi terkait dalam bidang pendidikan di sekolah.

Dari hasil wawancara dapat diketahui bahwa wacana yang menyebutkan bahwa keberadaan komite sekolah hanya sebagai formalitas memang benar adanya. Hal itu terjadi karena komite sekolah kurang memahami tujuan, fungsi dan apa saja yang menjadi perannya secara keseluruhan di sekolah, kurang berperannya komite sekolah juga dikarenakan kesibukan dari masingmasing pengurus dari komite sekolah. Disekolah swasta sendiri kurangnya peran dari komite juga dikarenakan keberadaan pihak sekolah. Meskipun demikian komite sekolah tetap harus menjalankan perannya sebagaimana tercantum dalam AD/ART sekolah walaupun hanya sebagian kecil saja.

\section{Dampak Peran Komite Sekolah dalam penyelenggaraan pendidikan di MTs Negeri 1 Palembang}

Kurang berperannya komite sekolah dalam pemberian pertimbangan khususnya disekolah swasta disebabkan oleh karena disekolah swasta kedudukannya sejajar dengan yayasan, lain halnya dengan sekolah negeri dimana komite sekolah mempunyai kedudukan tertinggi dan semua hal yang berhubungan dengan sekolah harus diketahui oleh komite sekolah. Disekolah swasta, yayasan lebih mempunyai kedudukan jadi apa yang berkaitan dengan opersaional sekolah harus dengan 


\section{Hagil Penelition}

persetujuan yayasan walaupun kadang juga meminta pertimbangan dari komite sekolah.

Seperti yang disampaikan narasumber RN di berikut: "Peran komite MTs Negeri 1 Palembang sebagai pendukung baik dalam pencapaian tujuan sekolah dan dalam meningkatkan mutu pendidikan. Dukungan yang diberikan komite sekolah berupa materiil dalam bentuk sarana yang belum ada disekolah dan dibutuhkan oleh sekolah selain itu juga berupa pemantauan terhadap kondisi dari pada tenaga pendidik dan non pendidik dalam hal ini adalah staf karyawan, selain itu dukungan yang diberikan juga berupa pemantauan kondisi sarana dan prasarana yang ada di sini (Nafiz, wawancara: 1-8-2016).

Peran komite sebagai pengontrol ditunjukan dalam bentuk pengawasan terhadap proses pengambilan keputusan disekolah, melakukan penilaian terhadap kualitas kebijakan yang diambil sekolah, melakukan pengawasan terhadap proses dan kualitas perencanaan dan program sekolah, melakukan pengawasan terhadap organisasi sekolah, melakukan pengawasan terhadap alokasi anggaran untuk pelaksanaan program sekolahdan melakukan pengawasan terhadap partisipasi sekolah pada program sekolah.

Beikut di sampaikan salah salah satu narasumber OR: “Komite MTs Negeri 1 Palembang juga berperan serta dalam rangka transparansi penggunaan alokasi dana pendidikan termasuk dalam mengawasi penggunaan dana bantuan dari pusat yang mengalir ke sekolah agar lebih dapat dipertanggungjawabkan. Penggunaan dana baik yang berasal dari masyarakat maupun pemerintah dapat benar-benar efektif dan termonitor alokasinya, apakah sesuai dengan Rancangan Anggaran (Oktorisman, wawancara: 1-8-2016).

Untuk menghindari hal tersebut dibutuhkan peran aktif dari komite sekolah, komite sekolah seharusnya tidak hanya mengawsasi penggunaan dana yang berasal dari pemerintgah daerah atau pusat saja tetapi juga mengawasi penggunaan dana yang berasal dari masyarakat atau wali murid. Tidak ikut sertanya komite sekolah dalam transprasi dana yang berasal dari orang tua murid sangat dimungkinkan terjadinya penyelewengan dana tersebut untuk hal yang tidak ada kaitannya dengan sekolah.
Sebagaimana dijelaskan oleh narasumber bapak ZA berikut: "Untuk menghindari kemungkinan tersebut komite sekolah bersama dengan pihak sekolah dan orang tua murid dapat mengadakan diskusi periodik untuk membahas perolehan dan penggunaan dana baik yang berasal dari pemerintah pusat atau daerah dan juga dana yang diperoleh dari orang tua murid. Sehingga penggunaan dana tersebut tepat sasaran yaitu untuk kemajuan sekolah (Abidin, wawancara: 3-82016).

Dengan adanya peran komite sekolah sebagai mediator antara sekolah dengan masyarakat maka akan mempermudah masyarakat dalam menyalurkan apa yang menjadi aspirasi mereka, dan apa yang menjadi aspirasi dari masyarakat dapat dijadikan masukan untuk sekolah sehingga sekolah dapat mengoreksi apa saja kekurangan yang ada disekolah dan secara bersama-sama antara masyarakat, sekolah, komite sekolah dapat mencari jalan keluarnya.

\section{Kesimpulan}

Berdasarkan hasil penelitian dan pembahasan. Penulis dapat menarik kesimpulan sebagai pernyataan singkat yang diharapkan dapat memberikan jawaban atas masalah yang diangkat dalam penelitian yaitu peran serta komite sekolah dalam meningkatkan mutu pendidikan di MTs Negeri 1 Palembang.

Peranan Komite Sekolah dalam penyelenggaraan pendidikan di MTs Negeri 1 Palembang:

Dukungan yang diberikan oleh komite sekolah dalam meningkatkan mutu pendidikan dalam bentuk materiil, materiil di sini dalam bentuk barang misalnya saja penambahan komputer, pemberian buku-buku pelajaran untuk melengkapi perpustakaan, komite juga memberikan dukungan moril kepada semua pihak sekolah supaya lebih mengembangkan mutu pendidikan.

Peran komite sekolah sebagai pemberi pertimbangan diwujudkan dalam bentuk pemberian masukan terhadap proses pengelolaan pendidikan di sekolah, memberikan masukan terhadap proses pembelajaran kepada guru-guru. Selain itu komite sekolah juga memberikan pertimbangan terhadap penyediaan dan penggunaan sarana dan prasarana yang bibutuhkan oleh sekolah. Komite sekolah juga 


\section{Hasil Penelitian}

memberikan pertimbangan terhadap penggunaan dan pemanfaatan anggaran atau dana yang diperoleh sekolah, memberikan masukan tentang rancangan anggaran pendapatan dan belanja madrasah (RAPBM), menyelenggarakan rapat rancangan anggaran pendapatan dan belanja madrasah (RAPBM), pertimbangan perubahan dan ikut mengesahkan RAPBM bersama kepala sekolah.

Selain itu komite sekolah juga berperan serta dalam rangka transparansi penggunaan alokasi dana pendidikan termasuk dalam mengawasi penggunaan dana bantuan dari pusat yang mengalir ke sekolah agar lebih dapat dipertanggungjawabkan. Penggunaan dana baik yang berasal dari masyarakat maupun pemerintah dapat benar- benar efektif dan termonitor alokasinya, apakah sesuai dengan Rancangan Anggaran Pendapatan dan Belanja Madrasah (RAPBM) yang diajukan satuan pendidikan/sekolah. Komite MTs N 1 Palembang juga mengadakan pengawasan pada pelaksanaan bimbingan belajar (kelas tambahan) khususnya pada kelas IX. Peran komite sebagai mediator sejauh ini wujudnya berupa penghubung antara kepala sekolah dengan masyarakat, kepala sekolah dengan dewan pendidikan serta kepala sekolah dengan sekolah itu sendiri dalam hal ini guru, staf karyawan dan murid, selain itu komite juga ikut serta dalam membuat usulan kebijakan dan beberapa program pendidikan kepada sekolah. Menjadi penampung aspirasi masyarakat dalam hal ini berupa pengaduan dan keluhan terhadap kebijakan dan program pendidikan dan menyampaikannya keluhan tersebut kepada instansi terkait dalam bidang pendidikan di sekolah.

Dampak peran Komite Sekolah dalam penyelenggaraan pendidikan di MTs Negeri 1 Palembang terlihat pada terlaksananya empat peran komite yang berpengaruh secara baik secara langsung maupun tidak, akan tetapi belum maksimal dalam menunjang penyelenggaraan pendidikan di MTs Negeri Palembang.

\section{Daftar Pustaka}

Aan Komariah \& Cepi Triatna. Visionary Leadership Menuju Sekolah Efektif. Jakarta: PT. Bumi Aksara. 2008.
Ade Irawan dkk. Mendagangkan Sekolah Indonesia. Jakarta: Corruption Watch. 2004

Basrowi dan Suwandi. Memahami Penelitian Kualitatif. Jakarta: PT. Rineka Cipta. 2008.

Bungin, Burhan. Metodologi Penelitian Kualitatif, Aktualisasi Metodologi ke Arah Ragam Varian Kontemporer. Jakarta: PT RajaGrafindo Persada. 2008.

Depdiknas. Undang-Undang SistemPendidikan Nasional Tahun 2003. Jakarta: CV. Tamiya Utama. 2003.

Fattah, Nanang. Ekonomi dan Pembiayaan Pendidikan. Bandung: Remaja Rosdakarya. 2000.

Fitri dkk. Manajemen Berbasis Sekolah. Palembang: Rafah Press. 2011.

Fuad Ihsan. Dasar-Dasar Kependidikan Komponen MKDK. Jakarta: PT Rineka Cipta. 2003.

Hidayat. Konsep Komite Sekolah di Indonesia. Bandung: PT Rosda Karya. 2004.

Mauludin. Manajemen Berbasis Sekolah. Jakarta: Pustaka Felicia. 2003.

Moedjiarto. Sekolah Unggul:Metodologi untuk Meningkatkan Mutu Pendidikan. Duta Graha Pustaka. 2003.

Moleong, Lexy J. Metodologi Penelitian Kualitatif. Bandung: PT Remaja Rosdakarya. 2006.

Muhlisin. Konsep Dasar Manajemen Peningkatan Mutu Berbasis Sekolah. Bandung: Cipta Rosda Karya. 2009.

Mulyasa, Enco. Manajemen Berbasis Sekolah Konsep, Strategi dan Implementasi. Bandung: PT. Rosada Karya. 2006

Musta'lim. Manajemen Peningkatan Mutu Berbasis Sekolah. Jakarta: Pustaka Felicia. 2009.

Nana Syaodih Sukmadinata, dkk. Pengendalian Mutu Pendidikan Sekolah Menengah. Bandung: Refika Aditama. 2006.

Nanang Fattah. Landasan Manajemen Pendidikan. Bandung: PT Remaja Rosda Karya. 2004

Syamsiah. Komite Sekolah di Era Modern. Jakarta: Pustaka Felichia. 2010 